\title{
CONDITIONS OF ACCOUNTABILITY FOR GENDER POLICY: THE ORGANIZATIONAL, POLITICAL AND COGNITIVE CONTEXTS
}

\section{Nüket Kardam}

\section{INTRODUCTION'}

Development projects usually include several actors: bilateral and multilateral development agencies, the non-governmental organizations (NGOs) and governments (including government agencies at national and local levels), and the recipients. The effectiveness of a project depends upon the cooperation of all these actors. If we assume that (a) motivation, based on incentives, determines performance in organizations, that (b) different kinds of organizations use different incentive structures, and that (c) ineffectiveness is the result of the failure to relate incentive to performance on a fair yet compulsory basis, then we need to clearly understand the differences in the incentives of IGOs, NGOs, and recipient governments. In each sector, the actors are both rewarded and hence motivated differently. In addition, in each sector incentives are linked to different sanctions. For example, in the public sector the state expects public officials to be motivated by vocation and thus carry out orders. In exchange, it guarantees incomes, recognizes professional autonomy and creates internal accounting systems, while forcing the minister to account to citizens at elections.

The enforcement of sanctions requires accountability: service providers have to be motivated to deliver the desired type and level of performance. This can be done by ensuring that the influence of the concerned stakeholders is reflected in the monitoring and incentive systems of service providers. If we accept that accountability is essential and that its 'effectiveness' will depend on whether effective sanctions exist through which that accountability can be enforced, then we need to know what conditions limit as well as promote accountability, in this case, gender accountability in different agencies. I define gender accountability as responsiveness to women's interests and the incorporation of gender-sensitive policies, programmes and projects both in state institutions and in donor agencies. What are the options open to stakeholders -

\footnotetext{
${ }^{1}$ I would like to thank the participants of the IDS Workshop on 'Getting Institutions Right for Women in Development', November 3-5, 1994 for their valuable comments and suggestions; I would also like to thank Jeffrey Yake for his research assistance.
}

in our case, beneficiaries, donors, members, and governments? As an example, Hirschman's (1970) concepts of 'exit' and 'voice' can provide useful tools in evaluating options. ${ }^{2}$

NGOs (international or domestic) and government agencies obtain resources (development assistance) from the state and from multilateral or bilateral donor agencies and provide services in exchange, and as such they are involved in explicit or implicit contracts in which their output must measure up in some way to what they have received.

Accountability then becomes the mechanism through which this relationship is regulated, one between principals and agents in which the former must create a system in which they can obtain the information required to monitor performance and create the incentives and sanctions required to ensure that the agents meet the obligations created through the receipt of funds or support.

(Brett 1993: 278-79)

Most of the development literature considers accountability solely as a political or an organizational issue. I will discuss accountability under three categories: the organizational, political and cognitive contexts, within which development programmes and projects are designed and implemented. Accountability has to do with the organizational characteristics (goals, procedures, staffing, incentive systems) of all agencies involved, as well as with the political context, i.e. the political commitment of the stakeholders to a project, whether the options of 'exit' and 'voice' are available, and whether democratic accountability exists. Finally, accountability cannot be discussed without understanding the 'discourse' underlying a particular policy area, in our case, gender policy. How do different stakeholders define 'gender issues'? On what basis should resources be allocated to women? What is perceived as the cause of gender constraints

\footnotetext{
2 The preceeding two paragraphs draw upon E.A. Brett's article 'Voluntary agencies as development organizations ...', Development and Change, Vol 24: 269-303 which I found very useful.
} 
will also determine what solutions are proposed. To what extent is there agreement between different stakeholders on the nature of the issue and the proposed solutions? These are some of the questions we might ask as we explore gendered institutions. Therefore, I will begin by analysing the conditions that limit and promote accountability ${ }^{3}$ within these three major categories: the organizational context, the political context, and the cognitive context.

\section{WHAT CONDITIONS AFFECT RESPONSIVENESS TO GENDER POLICY?}

\subsection{The organizational context}

\section{A Conflicting objectives of stakeholders}

The world of development assistance is populated by a large number of actors: NGOs (both as donors and beneficiaries), beneficiary populations, IGOs, and host country governments. Since each of these parties have differing and sometimes conflicting interests and leverage, difficult problems of monitoring and enforcement arise. Each actor would like to ensure effective performance, though their needs and criteria as well as their sources of information will differ. While the donors attempt to ensure appropriate performance, the recipients will wish to maximize their autonomy and resources.

Even when there is a seeming fit between project objectives and broader recipient and donor goals, effective performance cannot be guaranteed because such a fit does not reveal whether the project is a priority for the recipient or not. If it is not considered a priority (this means that the project objective specifically fits into policy priorities of recipient institutions and/or is supported by top officials in relevant recipient institutions), the project may serve implicit or unofficial priorities instead of official ones. In the case of developing country bureaucracies, securing autonomy - the power of independent action - is a priority and this can only be accomplished through the acquisition of resources. A high proportion of these resources are expended in maintaining the organization itself rather than in achieving specified goals. A very common way to 'maintain oneself" in developing countries is through patronage politics; resources are secured to acquire and maintain allies.
In order to capture resources, bureaucracies may accept unwanted projects. Once resources are secured, there is a tendency to abandon implementation and turn to the competition for the next round of resources on the part of high-level government staff. This means incentives for effective performance are vastly reduced. In the case of projects for women, governments may accept funds for such projects but may not necessarily have the interest or the will to implement them. We know that many projects that incorporate women are externally funded and it is not clear how sustainable they will be in the long run. Unofficial priorities are not just characteristics of recipient institutions; donor agencies may also have implicit goals such as the timely delivery of projects through the pipeline. One example is the World Bank: as a bank, it is a profit-making institution and therefore maximizing the number of loans made in the shortest amount of time possible may take priority. This emphasis on feeding the project pipeline encourages front-end planning, i.e. focusing on project design, preparation and appraisal rather than implementation and evaluation. This situation further weakens incentives for performance and its monitoring. As formal and informal goals diverge, commitment may be lost, communication problems may increase, and central direction may weaken.

A World Bank vocational training project in Turkey that ran into difficulties satisfying its objectives illustrates some of these organizational issues (Kardam 1992). The project objective, improving the supply of well-trained labour for manufacturing industries through vocational training, was in line with the export-oriented development strategy of the government, as well as the World Bank strategy to incorporate developing countries into the world market economy through increased exports. Yet most of the instructors who went abroad to be retrained (in areas of export business) returned to their previous jobs. This situation is partly derived from the lack of interest in the project by the Turkish authorities. There is so far no comprehensive human resource development policy in Turkey that establishes the links between education, employment, and certification. If vocational education was a priority area for the Ministry of National Education, perhaps broader policy reform that links education and employment could be established. Even though it is a declared goal, using education

${ }^{3}$ I will use 'responsiveness' and 'accountability' interchangeably in this article. 
to increase socioeconomic development is still secondary to its service to promote citizenship and national ideology. Vocational education in Turkey has a definite secondary status, since universities have been the avenue to respected, white-collar jobs. This lack of interest was reflected in the low level of involvement by high level bureaucrats in this project. It also affects the lower echelons of Turkish bureaucracy, who are not likely to devote attention to a project if they do not get the appropriate signals from their superiors.

\section{B Decentralization}

The world of development assistance is highly decentralized. As an example, the United Nations consists of a myriad of agencies that may be involved in the same project. Projects are implemented by international or national NGOs. The governments are further involved either as recipients of assistance, or in the case of the UN, as contributors of funds to their own projects. In my research on the UNDP's response to gender issues (Kardam, 1992), I found that the decentralized nature of the tripartite system (consisting of UNDP, UN specialized agencies and member governments) contributed to slow response to the Nairobi recommendations. Within this tripartite system, the UNDP is required to give first consideration for project execution to UN agencies with an appropriate specialization. Donor governments have a voice in UNDP affairs as contributors of funds, and recipient governments have come to regard the Indicative Planning Figures (IPFs) as firm commitments to their countries. Furthermore, recipient governments contribute funds to UN projects which gives them voice in the process. This system may lead to a lack of definition of responsibilities (with commensurate authority) regarding project management. In the case of gender issues, I found that this has led to 'passing the buck' and a disavowing-of-responsibility syndrome. The decentralized system has not been entirely unfavourable to the consideration of gender issues, however. It has at times allowed gender-sensitive UNDP staff to play the role of 'instigator' by bringing donors and recipient governments together to sponsor particular activities.

\section{Procedures of stakeholders, including finding indicators for success}

Procedures, broadly defined, include skills, knowledge, training of employees (including the approaches and strategies used) and decision making techniques (such as economic analysis, technical analysis, or analysis based on social science techniques). Particular procedures also provide staff members with particular perspectives or 'world views' on issues. A noteworthy point is that procedures of the donor and recipient both influence the project process and shape the project team's operations. Since gender policy formulation takes place within institutions, it is of the utmost importance to pay attention to specific organizations' goals and procedures in order to promote genderpositive institutional change. Whether gender policy is introduced in a way consistent with the goals and procedures of an organization greatly influences its response.

In my analysis of three development agencies, the World Bank, the UNDP and the Ford Foundation, I found that policy advocates took care to define gender issues in accordance with each agency's goals. For example, the World Bank's goals are to increase its profitability as a financial institution, and to promote economic growth for developing countries (with reliance on the market mechanism). To the extent that women in development (WID) issues were presented and justified in a way instrumental to these goals, they have been acceptable. Ultimately, the consideration of WID issues depends on the ability of its advocates to demonstrate greater benefit to cost ratios in order to elicit more resources. On the other hand, the Ford Foundation's more extensive response to WID can be explained by the greater correlation of WID with the Foundation's goals and procedures. The Foundation's goal to find innovative solutions to social problems rests on a value system that emphasizes equity and anti-discrimination. The root of social problems is seen as stemming from the unequal treatment and discrimination of some groups in society. Given that the objective of WID advocates is to enhance women's ability to contribute to and benefit from development on an equal basis with men, the relevance of gender issues is justified on the basis of the Foundation's goals and values (Kardam 1991) The Ford Foundation's procedures emphasize the search for and resolution of social problems. In fact, staff members are primarily social scientists with backgrounds in academia and research organizations. Finding solutions to social problems has meant support for the prodduction of new knowledge. When the Foundation enters a new area, it makes grants for basic research, applied research, and action programmes, in that order. 
This has proved to be an advantage in women's programming because research by and on women clearly helped to identify areas where action regarding women's programming was needed.

Procedures that are control-oriented tend to hinder flexibility and response to unforeseen circumstances, qualities that are especially needed in new areas like gender policy. Control-oriented procedures discourage frequent consultations between the donor, recipient and the project team, and may lead to misunderstandings and resentments. Procedural differences affect the project process even more if the organizations involved operate in different cultural and economic contexts, as they do in development projects. Project teams are accountable to several masters - that is, they have to work with at least two different organizations with quite different procedures. Even seemingly small procedural differences, such as differences in payment of foreign consultants and their local counterparts may create enough resentment to reduce motivation and incentives for effective performance considerably.

Monitoring mechanisms also present problems. Monitoring is especially costly where donors are funding services in remote foreign areas about which they have virtually no independent information. Official aid agencies subject to public scrutiny and accountability need to ensure that services are properly performed. Formal evaluations carried out by large donors are sometimes the most rigorous processes to which NGO projects are subjected. Yet these exercises are difficult in themselves as evaluators have limited time, local situations are very complex, and both field workers and beneficiaries will have a vested interest in ensuring that the service continues. They may therefore collude to conceal failures from evaluators.

Perhaps the major problem in the public sector is the difficulty involved in devising and enforcing rational success indicators. In the case of gender policy this is especially relevant, as there is disagreement on how it should be defined and implemented. ${ }^{3}$ As Brett (1993: 280-81) points out:

As long as non-market agencies are used for many purposes, we will have to make allocation decisions on the basis of imperfect success indicators which involve calculations based on subjective ideological judgments as much as on objectively measurable quantities ... Where objectives are in conflict - for example where participatory processes reduce the output derived from a given investment - the final assessment must be based upon a sum of the gains and the losses. This involves difficult philosophical and practical problems evaded in traditional economic analysis, but in real life social choices are commonly made on the basis of competing and incompatible objectives where non-material values often take precedence over material gains.

\section{Internal policy advocacy}

For a new issue to gain acceptance, its consistency or 'fit' with the organization's goals and procedures is necessary, though not sufficient for acceptance. A new issue which may be consistent with goals and procedures but without advocates willing to bargain on its behalf will not automatically be incorporated. Without the conscious effort of some people, sometimes called policy advocates or policy entrepreneurs, policies may never be formulated or implemented (Kardam 1992). Polsby (1984) suggests that policy innovations are initiated by interest groups and persons who actively identify new issues and who specialize in acquiring and deploying knowledge about them. He calls these people policy entrepreneurs who, by the skillful mobilization of facts which serve as justification for action and through the accurate identification and thoughtful cultivation of allies (i.e. political clout), bring a policy into being. By virtue of being inside an agency, they also build in accountability mechanisms by reviewing and revising policy documents, providing input to policy documents, attending high-level management meetings, suggesting new policies to the management and interviewing job candidates. Strategies to present facts as a basis for action range from holding seminars, writing background papers, inviting outside speakers, holding staff meetings, and providing input into programme development, to showing how a new issue fits the goals and procedures of the organization. If agencies don't have gender policy advocates working from within, then instigating gender-positive institutional change will be relatively more difficult.

\footnotetext{
4 I will discuss these issues in more detail in the section on the 'cognitive context'.
} 


\subsection{The political context}

\section{A Political commitment of stakeholders}

If politics means, according to one well-known definition, 'who gets what, when and how,' or the distribution of power in terms of both resources and influence, then the politics of international agencies, as well the politics at both national and local levels, will affect gender policy outcomes. Given the time constraints and the competing issues demanding attention from international and national bureaucrats, the question becomes 'why should one pay attention to gender issues at all?'

Lack of political commitment to a project hampers effectiveness because sanctions are ineffective or are not imposed, performance is not monitored and incentives for performance are weakened. In the development literature, the importance of political commitment to a project by the recipient country is emphasized (Grindle 1980). Obviously, developing country élites' (this includes both the responsible implementing agency and top government officials) commitment to the project increases the chances of success. If the project is not considered important, implementation will suffer; bureaucrats who are responsible will not give it priority. A discussion of political commitment should not just focus on the recipient side, however. Donor agencies are part of the political context of projects as well. As Heaver (1982: 39) puts it:

It cannot be stressed too strongly that it is a non-issue to raise a question whether agencies should be involved in the sort of recipient bureaucratic activity .... It is a non-issue because agencies have no choice: they are in the political game ... If funding agencies choose to adopt a do-nothing strategy, this is effectively a political decision to accept the present position. If agencies are serious about their official goals, the question is ... not whether they play politics, but how to be better at it than others.

Donor agencies may need to mobilize support among the government agencies and various groups in society in order to achieve project objectives. Parker and Friedman (1993) point out:

In spite of the differing interests, all these organizations are linked not only through their shared goal of enabling development but also because each entity needs the support of others for its change process to have a positive impact. For example, if an international US-based development organization makes a strategic change in its primary goals in favour of directly addressing unequal gender power relations, it cannot carry out this goal unless its donor organizations value and support such an approach.

\section{B Sensitivity to external pressure}

At the international level, the rise of the WID movement pressured development agencies and governments to put gender issues on the agenda. The United Nations recommendations resulting from several conferences on gender issues, the establishment of WID offices at many development agencies, and the WID bureaus and units within many governmental bureaucracies are the outcome of these pressures. Most recently, at the International Conference on Population and Development in Cairo, gender issues were put on the agenda clearly and centrally. The Programme of Action adopted by delegations from 179 states includes a chapter on 'Gender Equality, Equity and Empowerment of Women':

This chapter calls on countries to empower women and eliminate inequality between men and women, eliminate all forms of discrimination against the girl child and the root causes of son preference; increase public awareness of the value of girl children, beyond their potential for child bearing, and promote equal participation of women and men in all areas of family and household responsibilities.

(Populi October 1994)

At the same time, movements are at a disadvantage when it comes to institutionalization, including the establishment of accountability mechanisms, because the issues need to be broadly formulated to gain acceptance and because they generally are instituted from the outside rather than from within. Furthermore, development agencies' sensitivity to external pressures differ. Those actors that are relatively more independent would be less likely to be influenced by external pressure than those that are more dependent. The degree of independence has to do with an international organization's (IO) ${ }^{4}$ range of accountability to other actors. The narrower

4 Intemational organizations include intemational govemmental organizations, as well as international non-governmental 
the circle of accountability, the more independent an IO would be. For example, international nongovernmental organizations in the field of international development, such as the Ford Foundation, seem to be relatively more independent because their circle of accountability is very narrow: they are directly accountable only to a board of directors. The World Bank, however, a specialized UN agency, is probably not as independent as the Ford Foundation in its policies, but nevertheless more so than most United Nations agencies. The World Bank has a weighted voting system and is therefore accountable to those member states who provide the highest capital subscription. Many UN agencies, on the other hand, are much less independent, because their circle of accountability is quite wide: they are accountable to all member countries since the decision making process is based on a onemember, one-vote system. They are thus much more permeable and open to influence by all member governments, as well as by NGOs. Naturally, external influence, such as that exercised by the international women's movement, would have a different impact on different IOs, depending on their relative independence within the international development assistance regime. It is not necessarily the case, however, that more accountability is accompanied by increased effectiveness. Too much public voice can bring service delivery to a halt; excessive accountability may diminish effectiveness considerably. In fact, both the US Agency for International Development and the US State Department have been pointed out as organizations where accountability to diverse interests has reduced their effectiveness.

Even when international development agencies have become to responsive to gender issues, there is no guarantee that they can, in general, elicit compliance from recipient governments. We know that the issue of how to promote compliance for international norms and rules is a problem for all international regimes. According to Oran Young (1989), the lack of well-entrenched and properlyfinanced supranational institutions in international society ensures that international regimes must rely heavily on the ability and willingness of individual members to elicit compliance with key provisions within their own jurisdictions. I have argued elsewhere, drawing from a case study on Turkey (Kardam 1994), that international norms and rules may be very influential in prompting policy changes in a particular country, but whether these policy changes are more than words on paper depends on relationships between state and society. It is important to note that to propose that states make changes regarding women's roles and status creates deeper problems than just those of verification and policing. Issue areas which propose changes in the relationship between the national state and its subjects are especially sensitive, for as Krasner (1985:118) points out, prevailing international norms and practices place few inhibitions on a state's discretionary control over its own subjects. Yet, support for women's movements from outside is crucial for the survival of many national machineries for women that were established in response to the UN Conference in Nairobi in 1985. Alvarez (1990) points out that, in the past, international feminist solidarity successfully brought pressure to bear on the international development establishment, indirectly pushing Third World states to open up some political space, however minimal, for the articulation of progressive gender discourses and policies.

\section{State-society relationships}

States possess political institutions. These traditionally include constitutions, institutions of power such as legislatures, executives and judiciaries, and a means of promoting political views, often seen in the form of elections. Even though most of these elements are present in Western democracies as well as authoritarian regimes, in non-democratic settings questions may arise regarding the extent to which these institutions are held accountable. Third World states struggle to achieve certain goals: 'The central political and social drama of recent history has been the battle pitting the state and organizations allied with it (often from a particular social class) against other social organizations dotting society's landscape.' (Migdal 1988: 27) Within this context, those who make the rules acquire social control. In relatively new states, rules of the game are not necessarily agreed upon. State élites try to penetrate society, regulate social relationships, and extract resources with varying degrees of success. For example, the seemingly inconsequential conflict in Mustafa Kemal's Turkey over what kind of hat men should wear was, in fact, about who had the right and ability (religious élites or bureaucratic élites) to make rules.

The question of accountability becomes very important when introducing the term 'civil society' to the discussion of the state. If we define civil society as 
those institutions and groups below the state level that can challenge the state itself on certain issues, then the type of state must be considered. Presumably, a state that permits such groups to exist and advocate opinions in an unfettered manner can be classified as a democracy, or at least possessing democratic values. Authoritarian regimes, in contrast, would not likely allow such groups to exist at all, or only under strict control. The relationship between the state and civil society becomes particularly important when speaking of a system in transition, or a transition to democracy. Not only must one consider the institutional developments, but the existence of, or potential for, a civil society. For the latter to exist, the state must be receptive to possible sources of opposition, and allow its population to actively participate. There must be a political culture conducive to political action.

Accountability of state institutions for gender policy seem to increase to the extent that regimes are democratic and to the extent that there are women's organizations within civil society who demand it. For example, Alvarez argues that in transitional regimes, gender-specific demands may stand a greater chance of being met if women's mobilization is seen as necessary to consolidate the regime, solidify its legitimacy and achieve larger developmental goals (Alvarez:1990: 270).

\section{The uneven power between beneficiaries and agencies}

The beneficiaries of many development projects, especially where women are involved, are typically poor, ill-educated and vulnerable, with limited access to information. But accountability in development projects is not generally directed towards the beneficiaries, but rather towards the donors. As Brett (1993: 292-93) points out:

... in deprived environments, for example in Africa, neither exit nor voice are realistic options for the poor. Some NGOs try to 'empower' beneficiaries through participatory structures which encourage local communities to identify priorities, develop programmes ... These are commendable efforts, but they are time-consuming and depend on the goodwill of the agency. They do not give consumers any independent authority over the agency; only donors enforcing a budget can exercise such authority, so that in terms of evaluation, donors have to be seen as surrogates for consumers.
Brett goes on to suggest that local NGOs, once they have access to external sources, acquire a privileged position in the local community while potential beneficiaries may not know what their entitlements should be. Donors are unable to get reliable information about the groups, and accountability is greatly reduced, especially in poor communities dominated by patron-client networks.

Professional technicians and government bureaucrats are not rewarded for being responsive to local conditions nor contributing toward the development of local institutional capacities. Accountability is directed at actors different than the clients, which reduces the incentive to be responsive to client interests substantially. As Korten puts it (1980: 484)

The fact is that USAID is accountable to the US Congress and to agencies such as the Office of Management and Budget. Not surprisingly, the USAID programmer is more likely to be preoccupied with the needs and involvement of the groups that arbitrate his programme than with those of the poor beneficiaries.

Governments may be more easily adaptable to local problem-solving but may lack the political will to do so. To what extent would governments be interested in involving women beneficiaries in programmes and projects? It is clear that new participation changes the nature of the influence structure. Participation is inescapably political. Broader participation by women is likely to change the use and allocation of resources in society indeed, that is why it is often advocated.

\subsection{Cognitive context - the discourse of gender issues}

In order to promote any new policy, a gap between reality and the desired state has to be seen. Furthermore, reasons for the existence of such a gap need to be elaborated upon, so that based on these reasons, one can devise ways to overcome them. There is a wide diversity of views regarding why there is a gap between what exists and what the ideal state of gender issues in development should be, as well as how this gap should be overcome. (See Goetz in Grant and Newland (eds) 1991; Jaquette in Tinker (ed.) 1990 and Kardam 1987).

Gender and Development combines two broad theoretical issues: women's social, economic and 
political roles in society, and the nature of development itself. As is well known, international development agencies, governments, and NGOs differ on the definitions of both these issues. The international WID (Women in Development) movement itself has not been able to reach an agreement on any norms, mostly because the definitions had to remain broad and ambiguous in order to elicit cooperation from different actors. Looking briefly at gender relations, most would agree that the power relations between men and women are unequal and what women do is generally undervalued. The 'superior' party in an unequal relationship presumably has more of some ability or valuable quality. While these abilities vary with the particular relationship, they include emotional maturity, experience in the world, physical skills, and a body of knowledge or techniques for acquiring certain kinds of knowledge. Dominant actors usually define acceptable roles for subordinates. If gender relations are based on unequal power, then it is crucial to uncover how women's roles in society have been defined by men. We know that these are socially constructed roles and change depending on different societies, cultures and time. But definitions of women's roles typically involve providing services that men don't want to perform. The functions that men perform, on the other hand, tend to be guarded carefully and relatively closed to women (Miller 1976). According to Miller, a dominant group inevitably has the greatest influence in determining a cultures' overall outlook, its philosophy, morality, social theory, and even its science. The dominant group thus legitimizes the unequal relationship and incorporates it into society's guiding concepts. Thus a power relationship is legitimized and disguised as the 'normal', 'natural', and 'expected' way things should be. In the same way, gender relations become legitimized and are incorporated into organizational and state ideologies.

Turning to the discourse on gender, a major 'guiding concept' helping to legitimize the unequal relationship between men and women is the 'public/ private' distinction. Men, as the dominant group, have defined women's work as housework and child rearing and relegated it to the 'private' sphere, while maintaining control over the 'public' sphere of political power, law, and general public life (see, e.g. Ehlstain 1974). This distinction has been part of Western history since the Greeks. Capitalism and liberal theories of the state encouraged early Western feminist movements; however, women still remained within the confines of male-defined institutions. Liberalism meant equal opportunity for everyone; in other words, women could now compete with men on the basis of their capacity for reason. But at the same time, patriarchal institutions continued defining women as less capable of reason than men and as limited to the 'private sphere'.

These two concepts 'equal opportunity for all' and the 'public/private distinction' that maintained inequality between men and women could go hand in hand because 'equal opportunity' meant that women were given the opportunity to compete with men in male-defined institutions. Still, the abilities that are defined as valuable, such as the ability to reason or the ability to compete in the public realm, are defined by and reserved for men. Because such characteristics are defined as male characteristics, it can be deemed unsuitable, unseemly or simply impossible for women to acquire them. Women, by accepting this discourse on gender, inadvertently accept the arguments of their 'sexual inferiority'. The definitions of what women can and cannot do then become self-reinforcing, because women's knowledge of themselves is defined within the dominant discourses and therefore is not a realistic evaluation of their own capacities and problems. There are women who have internalized these dominant beliefs of gender roles who think that they are less important, less valuable, or less smart than men. This, of course, makes them more hesitant to venture into the public realm of international donor agencies, or state bureaucracies and demand accountability.

An example of gender discourses are reflected in government bureaucracies comes from Malawi. David Hirchman's interviews with Malawian bureaucrats reveals the denigration, compartmentalization, and trivialization of matters dealing with women's work. According to a senior official he interviewed (in Staudt 1986: 29):

Men's superiority here is customary - also it is Christian ... it is in the Bible. We expect our wives to respect us and despite talk of equality, we must lead ... we can compromise a bit, but we must lead. Women were meant to serve men; they can never be equal to men.

It is important to understand how gender relations are defined in specific contexts and what the perceived sources of inequality are. Depending on how the sources of gender inequality are defined, 
policy recommendations differ. If, for example, the reasons are seen as the infiltration of Western norms that undermine the traditional roles and the accompanying respect for women, then policy recommendations that follow would certainly not include exposing more women to the 'public sphere' and to competition with men. Instead they would include ways to maintain the 'equal but separate' status of women. This, for example, is how religious conservatives in Turkey generally view gender relations. If the reasons for unequal gender relations are seen as caused by exploitative economic relations as socialist feminists view them, then policy recommendations would include treatment of women from different socioeconomic backgrounds differently and devise different policies, for example, for urban middle class women, urban factory workers, domestic servants and peasant women in rural areas. On the other hand, if the crux of the issue is seen as the lack of opportunity for women within male-defined institutions, then policies are targeted to establishing space for women, and rewriting laws to promote women's interests.

The discourse on development, like the discourse on gender relations, also presents a vast and colourful array of definitions and policies that flow from these definitions. Since the issue is not gender issues per se, but gender and development, gender policy and practice have been interpreted, analysed and justified differently, depending on the discourse on development. When efficiency and economic growth are emphasized, the economic contributions of women to development are brought on the agenda. Policy recommendations then include ways to improve their contribution to national development through programmes and projects in training, education and employment for women. It is suggested that patriarchal norms, principles and institutions be dismantled to the extent that they interfere with women's contributions to economic growth. When equity, basic human needs and welfare issues dominate the discourse, the discussion turns to women in poverty and lacking in basic human needs. Recommended programmes and projects for women within this discourse include increasing literacy, providing loans for small-scale enterprises for women, providing upgraded technology to reduce hours of work and the like. More recently, with the introduction or the term empowerment into development, women's empowerment has become a topic of discussion. Policy recommendations that flow from this discourse are broader than the first two.
Women's empowerment now includes achieving control over one's life through expanded choices. The policy recommendations that would flow from this view deal with ways of resolving conflicts between women's productive and reproductive roles, e.g. child care, and men's shares in the maintenance of the family, as well as women's participation overall in the redefinition of gender relations and the meaning of development itself.

All policy is focused on the allocation of resources. How is allocation of resources to women viewed? Depending on whether the basis of such allocation is equality, merit or need would determine the institutions one targets for change (Jaquette 1990). Those that argue for equality would focus on legal institutions, while those that argue for a market allocation for resources would focus on how women could elicit more responsiveness from market institutions. If allocation to women is argued for on the basis of need, then welfare bureaucracies constitute the target. Therefore, it is very important to analyse the gender discourse in specific contexts so that it is clear from which institutions one demands responsiveness.

\section{STRATEGIES FOR GENDER-POSITIVE INSTITUTIONAL CHANGE}

\subsection{The exercise of leadership and the formation of alliances}

Effective leadership is necessary to move any issue forward. In the case of gender issues, Northern European donors have taken the lead and encouraged other donors to consider gender issues. Initiatives have also come from NGOs both in the North and South. WID entrepreneurs within agencies can request the assistance of gender-sensitive allies both in their agencies and outside. For example, a case study on the World Bank's experience in incorporation of sociological issues demonstrated the necessity of both external pressure and internal advocacy (Kardam 1993). The case study focuses on internal advocacy efforts in the World Bank by a group of staff members to incorporate sociological issues, especially in the area of involuntary resettlement, and tribal population rights. While external pressure played a large role in putting pressure on the World Bank, the insiders were the ones who introduced the issues in ways that fit the goals and procedures of the World Bank in an otherwise resistant environment, and forged links with outside allies. This contributed to new policy 
guidelines, to the hiring of more staff with social science training, and, in general, to the increased legitimacy of these issues in the World Bank.

Leadership is a matter of entrepreneurship; it involves a combination of imagination in inventing institutional options and skill in brokering the interests of numerous actors to line up support for such options. Expanding accountability will require a new coalition of gender-sensitive donor agencies, development practitioners in donor and recipient countries, as well as governments and NGOs. Women's' NGOs need to become more sophisticated in understanding how institutions work and how to promote change within them. For example, environmental NGOs have been relatively more successful in pressuring the World Bank for policy changes than women's NGOs (Siddharth 1994). Alliances between Southern and Northern NGOs for women's interests is also crucial. Alliances with powerful groups such as the police for women's groups have also proved beneficial; as Stewart (1994) points out, the effectiveness of Musasa, a NGO in Zimbabwe working on domestic violence was enhanced as a result of its constructive relationship with the Zimbabwe Republic Police. Alliances between NGOs and women's groups is another option. Korten argues that (1990: 200):

Those VOs [voluntary organizations] with women in development programmes are coming to appreciate the full potential of women as a development force and the extent to which their liberation may be a key to unlocking cultural constraints to needed economic and political change. This creates the natural basis for alliances with organizations engaged in the women's movement.

In addition, international commissions can be set up to monitor compliance; a basis for this exists in the series of international covenants on women's issues, managed by the UN Commission on Human Rights. This organization can be brought more centrally into WID compliance.

\subsection{Improved communication between women's NGOs and groups and state institutions}

Further democratization of societies will play a large role in eliciting responsiveness from governments. In this process, women's groups can play a very important role in promoting the strength of civil society and improving communications between themselves and the government. Unfortunately, in many authoritarian systems, states have been reluctant to allow voice to groups within society, and such groups have shunned government initiatives due to fears of cooptation.

The strengthening of civil society should lead to improved voice for women. Improved voice comes with empowerment. Uphoff and Esman point out that locally responsive organizations are facilitated by, and may indeed depend upon, relative equity in the ownership and control of land, since this reduces the risk that they will be captured by established élites. Likewise, there is danger in including in the same organization groups with inherently conflicting social and economic interests, such as incompatible ethnic groups or landowners and landless workers. In other words, the interest of certain groups in society may impede rural development efforts that involve the poor, including women. This is more the case in a highly stratified society.

\subsection{Higher level of education for women}

A higher level of education for women will clearly increase women's empowerment and their 'voice' both within society and within institutions. Women who are educated not only have fewer children but are also more aware of the options available to them. This would lead to increased representation of women in state institutions. Clearly, decisions emerging from state institutions would more nearly approximate the wishes of women if the staff of these institutions reflect the demographic characteristics of the general population.

\subsection{Commitment to a transformational development}

In order to achieve accountability for gender policy, ultimately, the definition of development needs to change. Thus, besides practical strategies, a redefinition of the development discourse and its acceptance into mainstream development policy is required for long-term change. Such a discourse would start with 'people-centered development'. As Korten (1990: 67) has defined it, development is a process by which the members of a society increase their personal and institutional capacities to mobilize and manage resources to produce sustainable and justly distributed improvements in their quality of life consistent with their own aspirations. 
Increased accountability will partly come from the political consciousness of women and the practical strategies that they use to demand it, but that is only half the story. Increased accountability is also a function of the values of the power holder. Is there such a thing as the responsible use of power; and if so, how can it be attained? If egotism and greed are deeply embedded in human nature, the human spirit needs to be strengthened so that power is redefined in 'positive-sum' terms rather than zerosum. As Korten (1990: 168) suggests, 'this new consciousness must view power not as a club to be used in the service of personal aggrandizement, but rather as a gift to be held in stew ardship to the service of the community and the human and spiritual fulfilment of all people.

In conclusion, it is clear that a discussion of accountability is crucial to 'get institutions right for women in development'. Furthermore, it is also crucial to understand the nature of gender relations and their incorporation into bureaucratic and political ideologies. This article argued that accountability to gender issues needs to be considered within political, organizational and discursive contexts simultaneously.

\section{REFERENCES}

Alvarez, Sonia, 1990, Engendering Democracy in Brazil, Princeton: Princeton University Press

Brett, E.A., 1993, 'Voluntary agencies as development organizations: theorizing the problem of efficiency and accountability', Development and Change, Vol 24: 269303

Charlton, S.E., Everett, Jana and Staudt, Kathleen (eds), 1989, Women, the State and Development, Albany: State University of New York Press

Ehlstain, J.B., 1974, 'Moral woman and immoral man: a consideration of the public-private split and its political ramifications,' Politics and Society, Vol 4 No 4

Grindle, Merilee, (ed.), 1980, Politics and Policy Implementation in the Third World, Princeton, N.J.: Princeton University Press

Grant, Rebecca and Newland, Kathleen, (eds), 1991, Gender and International Relations,Bloomington: Indiana University Press

Goetz, Anne Marie, 1991, 'Feminism and the claim to know: contradictions in feminist approaches to women in development,' in Rebecca Grant annd Kathleen Newland, (eds), Gender and International Relations, Bloomington: Indiana University Press

Heaver, Richard, 1982, 'Bureaucratic politics and incentives in the management of rural development', World Bank Staff Working Paper, No 537, Washington DC: World Bank

Hirschman, Albert O., 1970, Exit, Voice, and Loyalty, Massachussets: Harvard University Press

Jaquette, Jane, 1990, 'Gender and justice in economic development,' in Irene Tinker, (ed.) Persistent Inequalities: Women and World Development, Oxford: Oxford University Press

Kardam, Nüket, 1987, 'Social theory and women in development policy', Women \& Politics, Vol 7 No 4, Winter
—, 1991, Bringing Women In: Women's Issues in International Development Programmes, Boulder: Lynne Rienner

_- 1992, 'Donor agency priorities and developing country contexts: the case of vocational education projects in Turkey', Paper prepared for the Middle East Studies Association Annual Meeting, October 28-31, Portland, Oregon

- 1993 , 'Development approaches and the role of policy advocacy: the case of the World Bank', World Development, Vol 21, No 11: 1773-1786

- 1994, 'The state, gender policy and social change: an analysis from Turkey', in Gay Young and Bette Dickerson, (eds), Color, Class \& Country: Experiences of Gender, London: Zed Books

Korten, David, 1987, 'Third generation NGO strategies: a key to people centered development', World Development, 15, Autumn

1990, Getting to the 21st Century: Voluntary Action and the Global Agenda, West Hartford, Connecticut: Kumarian Press

Krasner, Stephen, 1985, Structural Conflict: The Third World Against Global Liberalism, Berkeley: University of California Press

Migdal, Joel, 1988, Strong Societies and Weak States, Princeton: Princeton University Press

Miller, J.B., 1976, Toward a New Pschology of Women, Boston: Beacon Press

Parker, Rani A. and Friedman, Michelle,1993, 'Gender and institutional change in international development', in Gay Young, Vidyamali Samarasinghe and Ken Kusterer, (eds), Women at the Center: Development Issues and Practices for the 1990s, West Hartford: Kumarian Press

Polsby, Nelson, 1984, Policy Innovation in the United States. New Haven, CT: Yale University Press

Populi, 1994, The UNFPA Magazine, Vol 21, No 9, October 
Staudt, Kathleen, 1984, 'Women's politics and capitalist transformation in sub-Saharan Africa,' Women in International Development Working Paper No 54, Michigan State University, April

(ed.), 1990, Women, International Development and Politics, Philadelphia: Temple University Press

Stewart, Sheelagh, 1994, Women organizing women: doing it backwards and in high heels', Paper presented at the Workshop on Getting Institutions Right for Women in Development, Institute of Development Studies, Sussex, 3-5 November
Seedarth, Veena, 1994, 'Gender participation: how can NGOs influence positive change in World Bank policy?', Paper presented at the Workshop on Getting Institutions Right for Women in Development, Institute of Development Studies, Sussex, 3-5 November

Tinker, Irene, (ed.), 1990, Persistent Inequalities: Women and World Development, Oxford: Oxford University Press

Young, Oran, 1989, 'The politics of international regime formation: managing natural resources and the environment', International Organization, Vol 43 No 3 : 349-375, Summer 